\title{
PENGEMBANGAN E-MODULE KIMIA BERBASIS EXE-LEARNING PADA MATERI LAJU REAKSI
}

\author{
Edolfin Manulang*, Roza Linda, Asmadi M. Noer
}

Program Studi Pendidikan Kimia, Fakultas Keguruan dan Ilmu Pendidikan Universitas Riau, Kampus Binawidya KM 12,5, Pekanbaru 28293, Riau, Indonesia

\begin{tabular}{l}
\hline Informasi Artikel \\
\hline Sejarah Artikel: \\
Diterima: 05-08-2019 \\
Disetujui : 15-07-2020 \\
Dipublikasikan: 20-07-2020 \\
\hline Keywords: \\
Chemistry e-module, \\
exe-learning, \\
reaction rates, \\
learning media \\
\hline
\end{tabular}

\section{A b s t r a k}

Penelitian ini bertujuan mengembangkan dan menghasilkan e-module kimia berbasis exe-learning pada materi laju reaksi yang valid berdasarkan penilaian validator. Penelitian ini dirancang menggunakan desain penelitian dengan model pengembangan Plomp, yang terdiri dari 4 fase yaitu ; (1) investigasi awal, (2) desain, (3)realisasi dan (4)validasi, uji coba dan revisi. Data berupa penilaian dan saran oleh tim validator, responden guru dan peserta didik. Aspek penilaian meliputi subtansi materi, desain pembelajaran, tampilan dan pemanfaatan software. Dari hasil penelitian, diperoleh nilai validasi dengan skor $94,35 \%$ oleh validator media dan $88,12 \%$ oleh validator materi. Skor respon pengguna oleh guru dan peserta didik masing-masing adalah $93,3 \%$ dan $92 \%$ dengan kriteria sangat baik.

\begin{abstract}
A b s tract
This study was conducted only to the extent development, according of this research to develop and produce electronic module exe-learning based on reaction rates that is valid for use in learning based on ratings validator. The research was designed by research design with Plomp design which consist of four (4) steps; (1) preliminary investigation, (2) design, (3) realization, and (4) validation, evaluation, revision. The data are the assessment by the validator teams, teachers and learners' respondent. The aspects of the assessment which are material substance, educational design, appearance and software. From the research, it gained validation value with score $94,35 \%$ from media validator and $88,12 \%$ from material validators. User response scores by teachers and learners were obtained $92,7 \%$ and $92 \%$, respectively with very good criteria.
\end{abstract}

\footnotetext{
*Alamat korespondensi:

e-mail: edolfinm@gmail.com

No. Telf: +6281267667121
} 


\section{PENDAHULUAN}

Bahan ajar merupakan seperangkat sarana atau alat pembelajaran yang berisikan materi pembelajaran, metode, batasan-batasan, dan cara mengevaluasi yang didesain secara sistematis dan menarik dalam rangka mencapai tujuan yang diharapkan, yaitu mencapai kompetensi atau subkompetensi dengan segala kompleksitasnya (Lestari, 2013). Penggunaan metode pembelajaran yang tepat sangat dibutuhkan agar tersampainya bahan ajar kepada peserta didik, salah satunya adalah dengan cara memanfaatkan perkembangan Teknologi Informasi dan Komunikasi (TIK). Iqbal (2008) menyatakan bahwa bahan ajar dapat dikelompokkan menjadi empat kategori, yaitu salah satunya bahan cetak seperti antara lain handout, buku, modul, lembar kerja siswa, brosur, foto/gambar, brosur/leaflet dan model/maket.

Nurma (2010) mengemukakan bahwa e-Module merupakan alat atau sarana pembelajaran yang berisi materi, metode, batasan-batasan, dan cara mengevaluasi yang dirancang sistematis dan menarik untuk mencapai kompetensi yang diharapkan sesuai dengan tingkat kompleksitasnya secara elektronik. Exe-learning merupakan salah satu program aplikasi open source yang dipergunakan untuk pembuatan bahan ajar berbasis e-learning. Kelebihan yang dapat diperoleh ketika kita membuat modul elektronik atau bahan ajar dengan aplikasi exe-learning yaitu mudah dijalankan bagi pemula yang tidak mengetahui bahasa pemrograman $H T M L$, memiliki desain yang sederhana, merupakan software gratis dan dibuka tanpa harus terkoneksi dengan internet, pengguna mudah menggunakan bahasanya, bisa digunakan di sistem operasi window maupun linux, dan standar keluaran exe-learning berupa Sharable Content Object Reference Model (SCROM) (Warjana, 2008).

Berdasarkan wawancara yang telah peneliti lakukan kepada beberapa guru mata pelajaran Kimia di salah satu SMA Negeri Pekanbaru, SMA Swasta Pekanbaru dan SMA Negeri di Kabupaten Pelalawan yang dilakukan pada bulan Februari 2018, menunjukkan bahwa materi laju reaksi merupakan salah satu materi yang sulit dipahami peserta didik karena merupakan materi gabungan antara konsep yang bersifat abstrak dan hitungan. Konsep laju reaksi yang termasuk sulit dipahami oleh peserta didik yaitu tentang teori tumbukan dan kinetika kimia. Hal ini disebabkan karena konsep tersebut membutuhkan visualisasi yang tampak sehingga peserta didik dapat memahami bagaimana tumbukan dalam suatu reaksi kimia. Dan hasil informasi lainnya ialah kegiatan pembelajaran di kelas masih bergantung pada buku paket dan bahan ajar cetak. Adapun menggunakan media elektronik pada saat mengajar, hanya menggunakan media Compact Disk $(C D)$, powerpoint, dan sejenisnya.

Penelitian mengenai pengembangan media pada materi laju reaksi pernah dilakukan oleh Harefa dan Purba (2019) telah mengembangkan e-module praktikum kimia berbasis eksperimen sederhana. Hasil penelitian ini diperoleh respons peserta didik terhadap e-module dengan nilai praktis 93.7\% dan modul yang dikembangkan efisien dan efektif digunakan dalam praktikum kimia. Iqbal (2016) telah mengusulkan pengembangan media multimedia flash interaktif pada materi Laju Reaksi. Kesimpulan dari hasil penelitian menunjukkan bahwa media pembelajaran ini dikategorikan baik serta layak digunakan dan diterapkan pada materi laju reaksi. Dengan Nilai persentase tanggapan siswa sebesar 80,38\% dengan kategori sangat baik dan persentase tanggapan guru sebesar 92,27\% dengan kategori sangat baik. Alasan dikategorikan sangat baik ialah sangat menarik perhatian pembaca, menumbuhkan motivasi, menjadi lebih mudah memahami materi laju reaksi, dan metode pembelajaran lebih bervariasi. Febriani et al., (2019) juga telah mengembangkan media pembelajaran interaktif menggunakan autoplay media studio pada pokok bahasan kepolaran senyawa dan bentuk molekul dan diperoleh respon guru dan peserta didik masing-masing sebesar 77,5\% dan 95,5\%.

Penelitian ini bertujuan untuk mengembangkan e-module kimia berbasis exe-learning pada materi laju reaksi dan diterapkan pada kelas XI SMA/MA di Pekanbaru. Media pembelajaran ini diharapkan dapat membantu guru dalam memfasilitasi peserta didik agar dapat membangun pengetahuannya sendiri sehingga pembelajaran menjadi lebih bermakna dan berpusat kepada peserta didik serta menjadikan peserta didik menjadi lebih aktif karena peserta didik dituntut untuk menemukan konsepnya sendiri. 


\section{METODE PENELITIAN}

Penelitian dilaksanakan di Fakultas Keguruan dan Ilmu Pendidikan Program Studi Pendidikan Kimia. Jenis penelitian yang dilakukan adalah desain penelitian (design research) dengan proses pengembangan mengacu kepada model pengembangan Plomp seperti ditunjukkan pada Gambar 1:

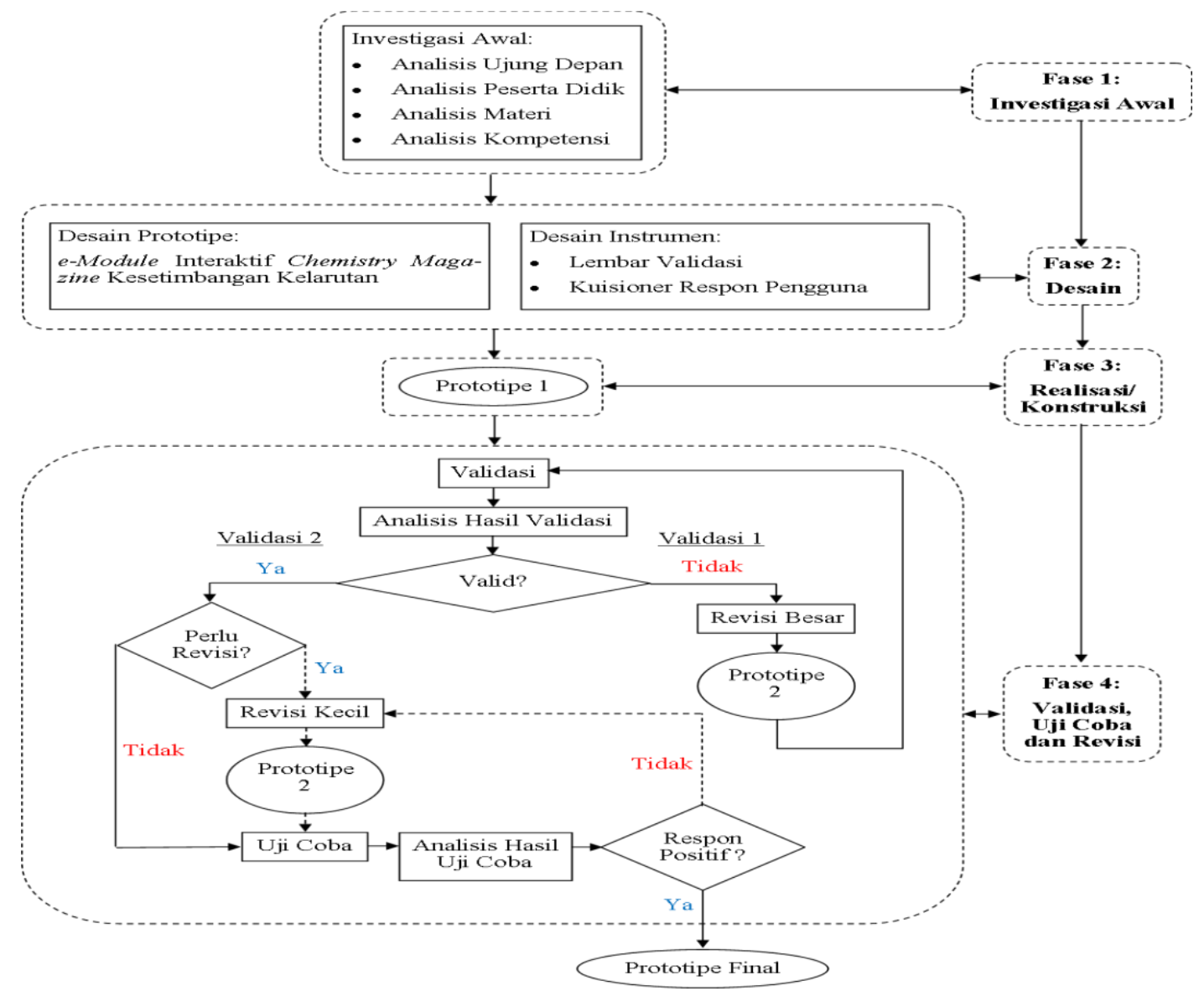

Gambar 1. Diagram alur pengembangan Plomp

\section{A. Fase Investigasi Awal}

Tahap awal penelitian dan pengembangan untuk mengetahui kebutuhan awal dalam mengembangkan e-module kimia berbasis exe-learning. Kegiatan pada fase ini meliputi: analisis ujung depan, analisis peserta didik, analisis materi dan analisis kompetensi.

\section{B. Fase Desain}

Tahap perancangan dilakukan untuk merancang desain awal secara garis besar e-module berbasis exe-learningyang akan dikembangkan. Kegiatan dari fase ini meliputi: melakukan rancangan awal (blueprint) e-module. Lembar validasi ahli materi dan ahli media, lembar responden guru dan peserta didik, dan susunan materi berdasarkan acuan dalam pembuatan media yaitu silabus.

\section{Fase Kontruksi}

Fase kontruksi merupakan fase selesai prototipe awal. Pada fase ini telah diperoleh $e$-module kimia berbasis exe-learning. Lembar validasi ahli media dan ahli materi, dan lembar responden guru dan peserta didik.

\section{Fase Validasi, Uji Coba, dan Revisi}

Pada fase ini merupakan proses mengembangkan produk e-module kimia berbasis exelearning pada materi laju reaksi, kemudian dilakukannya validasie-moduledan uji terbatas yang dilakukan pada guru dan peserta didik.

Objek penelitian yang dilakukan adalah e-module kimia berbasis exe-learningpada materi laju reaksi. Instrumen pengumpulan data adalah lembar validasi yang diberikan kepadaempat orang validator, lembar responden peserta didik yang diberikan kepada 30 orang peserta didik dan lembar responden guru yang diberikan kepada tiga orang guru untuk menguji kepraktisan penggunaan $e$ - 
module. Teknik pengumpulan data yang dilakukan pada penelitian dengan melakukan validasi perangkat pembelajaran kepada empat orang validator. Hasil penelitian dari validator akan menjadi data yang diolah oleh peneliti sehingga didapatkan hasil analisis data.

Teknik analisis data yang dilakukan adalah analisis deskriptifmenggunakan skala Likert dengan alternatif jawaban satu sampai empat sesuai dengan indikator penilaian. Untuk mengetahui tingkat kelayakan e-module kimia berbasis exe-learning ini dilakukan perhitungan persentase nilai validasi. Jumlah total jawaban validator ditentukan dengan mengalikan jumlah responden dengan bobot nilainya dan dijumlah semua hasilnya. Nilai persentase penilaian validator ditunjukkan pada Persamaan 1 dan skala penilaian validator diringkaskan pada Tabel 1.

$$
\text { Persentase }=\frac{\text { skor yang diperoleh }}{\text { skor maksimum }} \times 100 \%
$$

Tabel 1. Skala Penilaian Validator

\begin{tabular}{ccc}
\hline Kategori & Bobot Nilai & Persentase $(\%)$ \\
\hline Sangat Baik & 4 & $81,25-100$ \\
Baik & 3 & $62,5-81,25$ \\
Tidak Baik & 2 & $43,74-62,5$ \\
Sangat Tidak Baik & 1 & $25-43,75$ \\
\hline
\end{tabular}

\section{Angket Tanggapan Respons Pengguna}

\section{A. Angket tanggapan respons guru}

Data Lembar tanggapan diperoleh setelah tahap uji coba $e$-module. Data yang diperoleh dihitung, diklarifikasikan dan kemudian dianalisis secara deskriptif. Data yang diperoleh kemudian dianalisis secara kuantitatif dengan menggunakan skala Likert dengan alternatif jawaban Setuju (S) yang bernilai skor empat, Cukup Setuju (CS) yang bernilai skor tiga, Kurang Setuju (KS) yang bernilai skor dua dan Tidak setuju (TS) yang bernilai skor satu.

\section{B. Angket tanggapan respon peserta didik}

Lembar tanggapan peserta didik disusun berdasarkan skala Guttman. Jika dalam skala Likert memiliki interval yang fleksibel maka dalam skala Guttman hanya ada dua interval, yaitu 'setuju' dan 'tidak setuju' atau 'ya' dan 'tidak'. Interval "ya" bernilai skor satu dan interval "tidak" bernilai skor nol. Setelah jumlah data dari pengguna didapatkan, langkah selanjutnya adalah menentukan persentase tanggapan user dengan menggunakan Persamaan 2.

$$
R S_{\text {media }}=\frac{\mathrm{f}}{\mathrm{n}} \times 100 \%
$$

Dimana RS modul merupakan persentase skor respons pengguna (\%), f adalah jumlah skor yang diperoleh dan $\mathrm{n}$ ialah jumlah skor maksimum. Menentukan kategori respons positif berdasarkan persentase yang diperoleh. Jika perolehan persentase $\geq 50 \%$ maka respons peserta didik tergolong baik. Namun sebaliknya jika perolehan respons pengguna $<50 \%$ maka respons peserta didik tergolong tidak baik (Riduwan, 2013).

\section{HASIL DAN PEMBAHASAN}

Pengembangan e-module kimia berbasis exe-learning pada materi laju reaksi menggunakan jenis penelitian Design Research atau penelitian pengembangan dengan menggunakan model Plomp. Berikut adalah uraian langkah-langkah proses pengembangan e-module kimia berbasis exe-learning yang telah dilakukan.

\section{a. Fase investigasi awal}


Proses pengembangan e-module kimia dimulai dari tahap investigasi awal dengan melakukan analisis ujung depan, analisis peserta didik, analisis materi dan analisis kompetensi yang dilakukan untuk landasan dalam pembuatan e-module. Diawali dengan pemilihan pokok bahasan yang akan dikembangkan ke dalam e-module. Berlandaskan dari hasil pra-penelitian yang telah dipaparkan sebelumnya, laju reaksi dinilai sebagai materi yang bersifat abstrak yang membutuhkan pemahaman peserta didik terhadap konsep dasar dari kinetika reaksi. Pemilihan pokok bahasan laju reaksi juga didukung dengan dilakukannya wawancara dengan guru bidang studi kimia. Narasumber menyatakan bahwa laju reaksi merupakan materi yang cukup sulit untuk dipahami secara konsep oleh peserta didik. Selain dari sulitnya pokok bahasan laju reaksi, keterbatasan waktu di sekolah juga mempengaruhi proses pembelajaran.

\section{b. Fase Perancangan}

Fase perancangan pada e-module kimia berbasis exe-learning diawali dengan pembuatan rancangan awal modul yang berupa menu utama dan sub menu. Setelah rancangan awal ditentukan, dilanjutkan dengan menamai sub-sub menu yang sesuai dengan langkah-langkah pembuatan modul. Setelah itu melakukan pencarian isi dari e-module seperti isi materi, video, animasi flash, contoh soal, dan gambar.

\section{c. Fase Realisasi/Konstruk}

Tahap pengembangan e-module diawali dengan memilih warna background e-module. Selanjutnya, dilakukan pembuatan halaman awal (home) dengan mendesain halaman awal e-module seperti memasukkan gambar dan tulisan. Realisasi e-module dilakukan sesuai dengan historyboard yang telah dirancang pada tahap sebelumnya

\section{d. Fase Validasi, Uji Coba, dan Revisi}

Fase validasi dilakukan oleh empat validator yang terdiri dari dua validator ahli media dan dua validator ahli materi. Setiap validator menilai $e$-module sesuai dengan aspek penilaian $e$-module yang berlandaskan pada panduan pengembangan bahan ajar berbasis TIK oleh kementerian pendidikan nasional direktorat pembinaan SMA tahun 2010 yaitu aspek subtansi isi, desain pembelajaran, tampilan (komunikasi visual) dan aspek pemanfaatan software. Berikut rekap rata-rata penilaian keempat aspek kelayakan e-module yang dinilai dari 4 validator dapat dilihat pada Tabel 2.

Tabel 2. Rekap skor penilaian keempat aspek kelayakan $e$-module validasi I dan validasi II.

\begin{tabular}{ccccccccc} 
Validator & \multicolumn{3}{c}{ Aspek penilaian } & \multicolumn{3}{c}{ Rerata hasil (\%) } & $\begin{array}{c}\text { Rerata } \\
(\%)\end{array}$ & Kategori \\
\cline { 2 - 7 } & Isi & Desain & Tampilan & $\begin{array}{c}\text { Pemanfaatan } \\
\text { Software }\end{array}$ & & & & \\
\hline Ahli & 97,5 & 96,64 & 90,62 & 94,64 & V1 & V2 & 94,35 & Valid \\
Media & & & & & 92,63 & 91,2 & & \\
\hline Ahli & 87,5 & 87,5 & 90 & 87,5 & V3 & V4 & 88,12 & Valid \\
Materi & & & & & 85,20 & 91,04 & & \\
\hline
\end{tabular}

Catatan; V1 = Validator 1, V2= Validator 2, V3= Validator 3, V4=Validator 4

Berdasarkan Tabel 2 yang disajikan, hasil keseluruhan persentase rata-rata penilaian yang didapat ahli media sebesar 94,35\% dan ahli materi 88,12\% dengan kategori valid. Berdasarkan data hasil validasi dari keempat aspek kelayakan diatas, maka dibuat dalam bentuk diagram batang nilai rata-rata validasi dan ditunjukkan pada Gambar 2.

Pada tahap validasi, setelah ditunjukkan e-module yang berupa rancangan awal ke validator terdapat revisi yang harus dilakukan oleh peneliti. Revisi yang dilakukan berdasarkan pada masukan dan saran dari validator. Beberapa contoh saran dan masukan validator dan pengguna diperoleh selama proses pengembangan e-module kimia berbasis exe-learning diringkaskan dalam Tabel 3. 
Kemudian, setelah dilakukan revisi, dilakukan pemberian nilai oleh validator dengan cara menunjukkan e-module hasil revisi ke validator. Setelah penilaian didapatkan hasil secara keseluruhan oleh empat validator sebesar $91,23 \%$ dengan kategori valid sehingga e-module dapat di ujicobakan secara terbatas. Contoh hasil revisi yang dilakukan peneliti dalam proses pengembangan e-module kimia berbasis exe-learning yaitu: sebelum direvisi, tampilan media pada mata pelajaran dibagi menjadi tiga bagian dan hal tersebut kurang efisien dan memakan waktu yang banyak, sehingga diperbaiki dengan dilakukan penggabungan tiga materi menjadi satu file e-module. Berikut merupakan salah satu tampilan e-module yang sudah direvisi dapat dilihat pada Gambar 3.

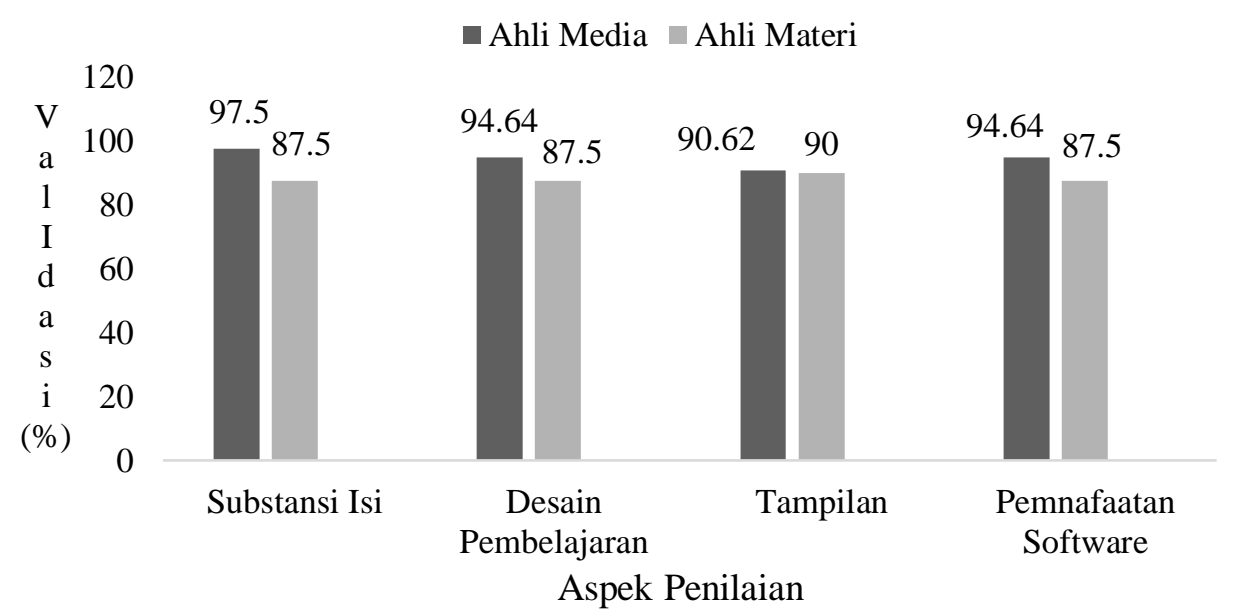

Gambar 2. Hasil validasi oleh ahli media dan ahli materi berdasarkan aspek penilaian

Tabel 3. Saran dan masukan validator dan pengguna

\begin{tabular}{|c|c|c|c|}
\hline No & Bagian & Saran dan Masukan & Tindak Lanjut \\
\hline 1 & $\begin{array}{l}\text { Materi defenisi } \\
\text { laju reaksi }\end{array}$ & $\begin{array}{l}\text { Ilustrasi tentang laju reaksi } \\
\text { tidak sesuai dengan defenisi } \\
\text { laju reaksi }\end{array}$ & $\begin{array}{l}\text { dilakukan pergantianIlustrasi laju } \\
\text { reaksi yaitu perbedaan laju pada } \\
\text { pembakaran kayu }\end{array}$ \\
\hline 2 & $\begin{array}{l}\text { Materi } \\
\text { tumbukan }\end{array}$ & $\begin{array}{l}\text { Penjelasan pada video animasi } \\
\text { tumbukan efektif dan tidak } \\
\text { efektif kurang jelas. }\end{array}$ & $\begin{array}{l}\text { dilakukan pergantian video yang lebih } \\
\text { jelas mengenai teori tumbukan efektif } \\
\text { dan tumbukan tidak efektif. }\end{array}$ \\
\hline 3 & $\begin{array}{l}\text { File e-module laju } \\
\text { reaksi }\end{array}$ & $\begin{array}{l}\text { Pembagian e-module menjadi } \\
\text { tiga bagian ( } 3 \text { file }) \text { kurang } \\
\text { efektif untuk digunakan. }\end{array}$ & $\begin{array}{l}\text { Dilakukan penggabungan tiga file } e \text { - } \\
\text { module menjadi satu file } e \text {-module }\end{array}$ \\
\hline
\end{tabular}

Uji coba kepada guru responden dilakukan secara langsung dihadapan peneliti menggunakan laptop. Uji coba ini diawali dengan pengoperasian e-module kimia berbasis exe-learning pada materi laju reaksi oleh guru responden yang bersangkutan. Setelah berbagai fitur dalam e-module kimia berbasis exe-learning pada materi laju reaksi dioperasikan secara tuntas, guru responden kemudian diberikan kuesioner respon pengguna oleh guru dan melakukan penilaian terhadap e-module kimia berbasis exe-learning pada materi laju reaksi seraya berdiskusi kecil dengan peneliti. 


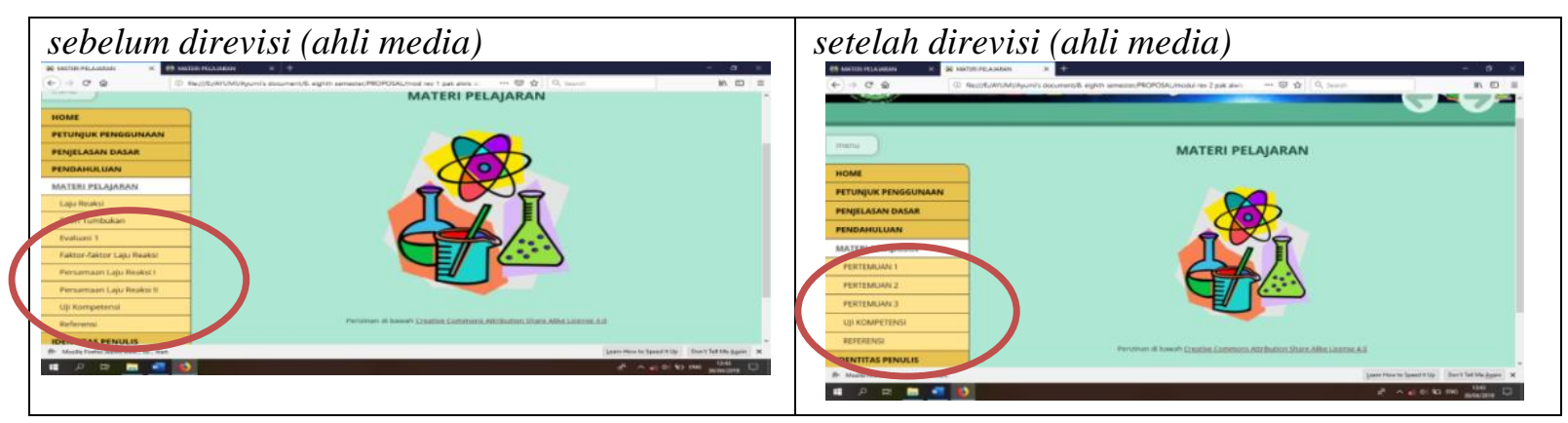

Gambar 3 Contoh tampilan e-module kimia berbasis exe-learning

Uji coba kepada peserta didik responden dilakukan secara langsung oleh peneliti dan didampingi guru kimia bersangkutan yang sebagian besar menggunakan laptop. Uji coba ini diawali dengan pengumpulan peserta didik sebagai responden oleh guru kimia bersangkutan dan peneliti memberikan penjelasan singkat terkait penggunaan e-module kimia berbasis exe-learning laju reaksi dan kilas balik materi laju reaksi agar peserta didik responden dapat mengingat kembali konsep yang terdapat pada materi tersebut. Kemudian, masing-masing peserta didik diberikan kuesioner respons pengguna oleh peserta didik.

Uji coba terbatas yang dilakukan untuk melihat respon peserta didik terhadap e-module kimia berbasis exe-learning pada pokok bahasan laju reaksi menggunakan lembar tanggapan/respon peserta didik. Rekapitulasi hasil respons peserta didik terhadap e-module kimia berbasis exe-learning diringkaskan pada Tabel 4.

Tabel 4 Rekapitulasi hasil respons pengguna e-module

\begin{tabular}{lcl}
\hline \multicolumn{1}{c}{ Responden } & Rata-rata Perolehan Nilai & Kategori \\
\hline Guru & $93,3 \%$ & Sangat Baik \\
Peserta didik & $92 \%$ & Sangat Baik \\
\hline
\end{tabular}

Berdasarkan Tabel 4, dapat dilihat bahwa hasil respons rata-rata peserta didik secara keseluruhan sebesar 92\% dan respon guru sebesar 93,3\%, yang mana menurut Riduwan (2013) bila hasil uji coba dengan menggunakan skala Guttman > 50\%, masuk ke dalam kategori baik.

\section{KESIMPULAN DAN SARAN}

\subsection{Kesimpulan}

Berdasarkan hasil penelitian, analisis pengolahan data dan pembahasan pada pengembangan e-module kimia berbasis exe-learning yang telah dilakukan didapatkan kesimpulan sebagai berikut: kualitas e-module dikategorikan valid berdasarkan penilaian validasi dan kepraktisan dengan Persentase keseluruhan hasil validasi media dan materi sebesar 94,35\% dan 88,12\%.

\subsection{Rekomendasi}

Penelitian hanya dilakukan sebatas mengembangkan e-module pada materi laju reaksi yang diuji secara terbatas. Untuk itu, diperlukan penelitian lebih lanjut pada fase implementasi guna menguji keefektifan produk dalam proses kegiatan pembelajaran. 


\section{DAFTAR PUSTAKA}

Creswell, J.W. (2015). Penelitian Kualitatif Dan Desain Riset. International Journal of Physiology, 3(1), 674. www//compas.com

Febriani, P., Holiwarni, B., Yasmi. E. 2019. Pengembangan media pembelajaran interaktif berbasis autoplay media studio 8.5 pada subpokok materi kepolaran senyawa dan bentuk molekul untuk kelas x SMA/MA. Jurnal Pendidikan Kimia Universitas Riau. 4(1); 36-47

Harefa, N., Purba. L.S.L. 2019. Pemanfaatan e-module praktikum kimia berbasis eksperimen sederhana. Simposium Nasional Ilmiah dengan tema: (Peningkatan Kualitas Publikasi Ilmiah melalui Hasil Riset dan Pengabdian kepada Masyarakat), Tanggal 7 November 2019; 298-303

Iqbal, M. 2008. Laporan Pengembangan Kurikulum Biologi SMA Kelas X Bahan Ajar Brosur Struktur Kimiawi DNA. (Online) http://lib.univ-malang.ac.id. (Diakses pada 30 Appril 2018)

Kemendiknas. 2010. Panduan Pengembangan Bahan Ajar Bebasis TIK. Dirjen Manajemen Pendidikan Dasar dan Menengah. Jakarta.

Lestari, I. 2013. Pengembangan Bahan Ajar Berbasis Kompetensi. Akademia. Padang.

Nurma. 2010. Bimbingan dan Konseling. (Online).http://nurmabimbingankonselingmantuban.blogspot.co.id/ (Diakses 08 Februari 2018).

Riduwan. 2013. Skala Pengukuran Variabel-variabel Penelitian. Penebit Alfabeta. Bandung.

Iqbal, S.M. 2016. Pengembangan Media Berbasis Intertekstual dengan Menggunakan Media Flash Interaktif pada Materi Laju Reaksi. Skripsi (tidak dipublikasikan). Fakultas Ilmu Tarbiyah dan Keguruan. UIN Syarif Hidayatullah. Jakarta

Warjana dan Razaq, A. 2008. Membuat Bahan Ajar Berbasis Web dengan eXe. Elexmedia Komputindo. Jakarta. 